\title{
PENINGKATAN APRESIASI KONSEP KARYA TARI BERBANTUAN MEDIA REKAMAN AUDIO VISUAL PADA SISWA KELAS IX SEMESTER 2 SMPN 1 PECALUNGAN TAHUN PELAJARAN 2019/2020
}

\author{
ABDUL AZIS \\ SMP Negeri 1 Pecalungan, Kabupaten Batang Jawa Tengah \\ Email : azisdumara@gmail.com
}

\begin{abstract}
ABSTRAK
Penelitian ini mempunyai tujuan meningkatkan pengembangan model pembelajaran dikelas terutama pendekatakan pembelajaran kontekstual berbantuan media rekaman audio visual. Penelitian Best Practice ini memberikan manfaat, antara lain bagi guru sebagai media peningkatan pengembangan model pembelajaran di kelas terutama pendekatakan pembelajaran kontekstual berbantuan media rekaman audio visual. Selain itu juga dapat menerapkan model pembelajaran yang tepat di kelas, mengingat karakteristik siswa yang bermacam-macam. Penelitian Best Practice ini juga memiliki manfaat bagi siswa, yaitu dapat meningkatkan apresiasi seni yang optimal pada mata pelajaran seni tari, dapat meningkatkan kreativitas siswa dalam belajar seni tari.. Metode penelitian ini adalah Best Pactice menerapkan pembelajaran dengan model pembelajaran Problem Based Learning (PBL). Subyek penelitian merupakan siswa kelas IXG sebanyak 29 siswa dan IXA sebanyak 32 SMP Negeri 1 Pecalungan Tahun Pelajaran 2019/2020. Bahan yang digunakan dalam Best Pactice ini adalah materi seni budaya (seni tari) kelas IX semester 2 tentang memeragakan tari kreasi. Hasil penelitian Best Practice bahwa materi pembelajaran yang selama ini selalu disajikan dengan pola deduktif (diawali ceramah teori tentang materi yang dipelajari, pemberian tugas dan pembahasan), membuat siswa cenderung menghapalkan teori. Pembelajaran seni budaya (seni tari) Konsep Karya Tari yang dilakukan dengan menerapkan model pembelajaran Problem Based Learning berlangsung aktif. Siswa menjadi lebih aktif merespon pertanyaan dari guru, termasuk mengajukan pertanyaan pada guru maupun temannya. Aktifitas pembelajaran yang dirancang sesuai sintak Problem Based Learning mengharuskan siswa aktif selama proses pembelajaran. Pembelajaran seni budaya (seni tari) Konsep Karya Tari yang dilakukan dengan menerapkan model pembelajaran Problem Based Learning meningkatkan kemampuan siswa dalam melakukan transfer knowledge. Setelah membaca, meringkas, mendiskusikan buku teks dan menyaksikan video tari Nusantara serta tari Mancanegara, siswa tidak hanya memahami pengetahuan konseptual dan pengetahuan prosedural, tetapi juga memahami konsep apresiasi dan berkarya tari. Penerapan model pembelajaran Problem Based Learning meningkatkan kemampuan siswa untuk berpikir kritis. Siswa menjadi lebih aktif merespon pertanyaan dari guru, termasuk mengajukan pertanyaan pada guru maupun temannya. Dalam pembelajaran ini pemahaman siswa tentang konsep karya tari benar-benar dibangun oleh siswa melalui pengamatan dan diskusi yang menuntut kemampuan siswa untuk berpikir kritis. Dengan menerapkan PBL, siswa tidak hanya belajar dari buku teks tulis, tetapi juga dari video serta diberikan kesempatan terbuka untuk mencari data, materi dari sumber lainnya.
\end{abstract}

Kata Kunci : Konsep Karya Tari, Media Rekaman Audio Visual

\section{PENDAHULUAN}

Seni tari merupakan salah satu unsur kebudayaan bangsa Indonesia yang sangat diperhatikan oleh seluruh bangsa kita. Hal ini telah ditegaskan dalam UUD.1945 pasal 32, yang rumusannya sebagai berikut : (1) kebudayaan banngsa ialah kebudayaan yang timbul sebagai sebuah usaha budi rakyat Indonesia seluruhnya. (2) kebudayaan lama dan asli yang terdapat sebagai puncak-puncak kebudayaan di daerah-daerah di seluruh Indonesia, terhitung sebagai kebudayaan bangsa. (3) Usaha kebudayaan harus menuju kearah kemajuan adab, budaya dan persatuan, dengan tidak menolak bahan-bahan baru dari kebudayaan asing yang dapat 
memperkembangkan atau memperkaya kebudayaan bangsa sendiri, serta mempertinggi derajat kemanusiaan bangsa Indonesia. Muatan seni budaya sebagaimana yang diamanatkan dalam Peraturan Pemerintah Republik Indonesia Nomor 19 tahun 2005 tentang Standar Nasional Pendidikan tidak hanya terdapat dalam satu mata pelajaran karena budaya itu sendiri meliputi segala aspek kehidupan. Dalam mata pelajaran Seni Budaya, aspek budaya tidak dibahas secara tersendiri tetapi terintegrasi dengan seni. Karena itu, mata pelajaran Seni Budaya pada dasarnya merupakan pendidikan seni yang berbasis budaya. Pendidikan Seni dan Budaya diberikan di sekolah karena keunikan, kebermaknaan, dan kebermanfaatan terhadap kebutuhan perkembangan peserta didik, yang terletak pada pemberian pengalaman estetik dalam bentuk kegiatan berekspresi/berkreasi dan berapresiasi melalui pendekatan : "belajar dengan seni," "belajar melalui seni" dan "belajar tentang seni." Peran ini tidak dapat diberikan oleh mata pelajaran lain. Pendidikan Seni Budaya memiliki sifat multilingual, multidimensional, dan multikultural. Multilingual bermakna pengembangan kemampuan mengekspresikan diri secara kreatif dengan berbagai cara dan media seperti bahasa rupa, bunyi, gerak, peran dan berbagai perpaduannya. Multidimensional bermakna pengembangan beragam kompetensi meliputi konsepsi (pengetahuan, pemahaman, analisis, evaluasi), apresiasi, dan kreasi dengan cara memadukan secara harmonis unsur estetika, logika, kinestetika, dan etika. Sifat multikultural mengandung makna pendidikan seni menumbuhkembangkan kesadaran dan kemampuan apresiasi terhadap beragam budaya Nusantara dan mancanegara. Hal ini merupakan wujud pembentukan sikap demokratis yang memungkinkan seseorang hidup secara beradab serta toleran dalam masyarakat dan budaya yang majemuk. Pendidikan Seni Budaya memiliki peranan dalam pembentukan pribadi peserta didik yang harmonis dengan memperhatikan kebutuhan perkembangan anak dalam mencapai multikecerdasan yang terdiri atas kecerdasan intrapersonal, interpersonal, visual spasial, musikal, linguistik, logik matematik, naturalis serta kecerdasan adversitas, kecerdasan kreativitas, kecerdasan spiritual dan moral, dan kecerdasan emosional. Bidang seni rupa, musik, tari, dan teater memiliki kekhasan tersendiri sesuai dengan kaidah keilmuan masing-masing. Dalam pendidikan seni budaya, aktivitas berkesenian harus menampung kekhasan tersebut yang tertuang dalam pemberian pengalaman mengembangkan konsepsi, apresiasi, dan kreasi. Semua ini diperoleh melalui upaya eksplorasi elemen, prinsip, proses, dan teknik berkarya dalam konteks budaya masyarakat yang beragam. (BSNP/Permendiknas 22/2006). Pendidikan seni tari tidak dipelajari secara sungguh-sungguh oleh sebagian besar siswa, dengan berbagai alasan, seperti materi ujian nasional hanya beberapa mata pelajaran saja, dan tidak termasuk pendidikan seni.

Pembelajaran seni tari di SMP cenderung menggunakan model konvensional yaitu guru memberikan contoh ragam tari dengan demonstrasi, kemudian siswa diminta untuk menirukan, sehingga harapan menjadikan siswa yang memiliki kompetensi untuk menuju pengembangan yang kreatif belum tampak. Langkah-Iangkah tersebut kiranya masih perlu diperkuat dengan strategi pembelajaran yang lebih tepat dan efektif, inovatif, agar siswa dapat memahami konsep dan pentingnya seni budaya, dapat nampilkan sikap apresiasi terhadap seni budaya, berkreativitas melalui seni budaya serta mampu menampilkan peran serta dalam seni budaya dalam tingkat lokal, regional, maupun global. Dengan demikian akan lebih baik apabila lebih banyak memberi kesempatan kepada siswa untuk mendapatkan pengalaman berapresiasi seni melalui rekaman video, sehingga pembelajaran seni tari yang diisyaratkan dalam kurikulum dapat tercapai.

Problem Based Learning (PBL) merupakan pendekatan pembelajaran yang diawali dari pemberian masalah kepada siswa yang penyelesaiannya menggunakan situasi yang nyata dalam kehidupan sehari-hari, sehingga siswa akan mengembangkan pengetahuannya untuk menyelesaikan masalah tersebut. Pendekatan pembelajaran ini dapat digunakan untuk melatih dan meningkatkan keterampilan berpikir kritis dalam memecahkan masalah, serta mendapatkan pengetahuan konsep-konsep penting. Pendekatan pembelajaran ini mengutamakan proses belajar, dimana tugas guru harus memfokuskan diri untuk membantu peserta didik mencapai 


\section{PAEDAGOGY : Jurnal Ilmu Pendidikan dan Psikologi \\ Vol. 1 No. 1 Juni 2021 e-ISSN : 2797-3344 P-ISSN : 2797-3336}

keterampilan mengarahkan diri. Dengan menggunakan pendekatan tersebut, penilaian dapat dilaksanakan secara menyeluruh yang meliputi kemampuan kognitif, afektif, dan psikomotor.

Menurut Ibrahim dan Nur (2000:2). Pembelajaran berbasis masalah digunakan untuk merangsang berpikir tingkat tinggi dengan situasi berorientasi pada masalah, termasuk didalamnya bagaimana siswa belajar. Pada waktu guru dapat menciptakan lingkungan belajar di kelas yang terbuka dan membimbing pertukaran gagasan antara siswa, dari sini pembelajaran berdasar masalah dapat dilakukan. Model pembelajaran berdasar masalah meliputi lima tahap, yaitu : (1) Peserta didik berorientasi pada masalah. Pada tahap ini guru menjelaskan tujuan pembelajaran, menjelaskan logistik yang diperlukan, memotivasi peserta didik terlibat dalam aktivitas pemecahan masalah dan mengajukan masalah.(2) Mengorganisasi, pada tahap ini guru membagi peserta didik ke dalam kelompok, membantu peserta didik mendefinisikan dan mengorganisasikan tugas belajar yang berhubungan dengan masalah. (3) Membimbing penyelidikan individu maupun kelompok. Pada tahap ini guru mendorong peserta didik untuk mengumpulkan informasi yang sesuai, melaksanakan penyelidikan untuk mendapatkan penjelasan dan pemecahan. (4) Mengembangkan dan menyajikan hasil karya. Pada tahap ini guru membantu peserta didik dalam merencanakan dan menyiapkan hasil karya. (5) Menganalisis dan mengevaluasi proses pemecahan masalah. Pada tahap ini guru membantu peserta didik untuk melakukan refleksi atau evaluasi terhadap penyelidikan mereka dan proses yang mereka gunakan.

Berdasarkan latar belakang tersebut maka peneliti mengangkat permasalahan dengan judul "Peningkatan Apresiasi Konsep Karya Tari Berbantuan Media Rekaman Audio Visual Pada Siswa Kelas IX Semester 2 SMPN 1 Pecalungan Tahun Pelajaran 2019/2020”. Best Practice ini mempunyai tujuan meningkatkan pengembangan model pembelajaran dikelas terutama pendekatakan pembelajaran kontekstual berbantuan media rekaman audio visual. Penelitian Best Practice ini memberikan manfaat, antara lain bagi guru sebagai media peningkatan pengembangan model pembelajaran di kelas terutama pendekatakan pembelajaran kontekstual berbantuan media rekaman audio visual. Selain itu juga dapat menerapkan model pembelajaran yang tepat di kelas, mengingat karakteristik siswa yang bermacam-macam. Penelitian Best Practice ini juga memiliki manfaat bagi siswa, yaitu dapat meningkatkan apresiasi seni yang optimal pada mata pelajaran seni tari, dapat meningkatkan kreativitas siswa dalam belajar seni tari.

\section{Pengertian Apresiasi}

Pendidikan seni memiliki peranan dalam pembentukan pribadi siswa yang harmonis antara logika, etika, rasa estetis dan artisik dalam pengembangan kreativitas, dan dalam penumbuhan kesadaran dan kemampuan berapresiasi terhadap keragaman budaya (Masunah, 2003: 123). Apresiasi yang dimaksud disini mencangkup kegiatan perolehan persepsi, pengetahuan, pengertian, analisis, penilaian, keterlibatan, dan penghargaan pada seni. Menurut Khisbiyah (2004: 17 ) apresiasi adalah kegiatan komunikasi siswa dengan seni. Apresiasi adalah semua hubungan seseorang dengan kesenian. Termasuk apresiasi adalah persepsi, pengetahuan, pengertian, analisis, keterlibatan, penghargaan, penikmatan, dan reaksi atau respons. Konsep apresiasi mencangkup pendidikan rasa. Apresiasi dapat diajarkan dengan metode belajar, misalnya, uraian mengenai sejarah kesenian, latar belakang sosial, teknik pertunjukan atau pembuatan, dan konsep analitis. Apresiasi juga bisa diajarkan secara langsung. Misalnya, siswa menonton pertunjukan atau pementasan, mendengarkan rekaman, menonton video, dan berpraktik serta berimprovisasi sendiri dengan instrument dan unsur-unsur kesenian lainnya. Pendidikan seni tari di sekolah seharusnya diberikan dengan pendekatan apresiasi. Pendidikan seni tari dengan pendekatan apresiasi dimaksudkan untuk menumbuhkan minat dan apresiasi siswa untuk menghargai dan menikmati seni tari. Di samping itu, pendididkan seni dengan pendekatan apresiasi diharapkan dapat membantu peserta didik memanfaatkan alam di sekeliling mereka sebagai inspirasi untuk mengembangkan rasa sehingga menumbuhkan rasa kesadaran tentang keindahan yang dirasakan, dilihat, didengar, dan dinikmatinya. 


\section{Konsep Karya Tari}

Seni tari yaitu gerak badan secara berirama yang dilakukan ditempat serta waktu tertentu buat keperluan pergaulan, mengungkap perasaan, maksud, serta pikiran. Bunyi-bunyian yang dimaksud musik pengiring tari mengatur gerakan penari serta menguatkan maksud yang mau disampaikan. Gerakan tari tidak sama dari gerakan sehari-hari seperti lari, jalan, atau bersenam. Gerak didalam tari tidaklah gerak yang realistis, tetapi gerak yang sudah diberi bentuk ekspresif serta estetis. Suatu tarian sesungguhnya adalah kombinasi dari sebagian buah unsur, yakni wiraga (raga), Wirama (irama), serta Wirasa (rasa). Ketiga unsur tersebut melebur jadi bentuk tarian yang serasi. Unsur paling utama dalam tari yaitu gerak. Gerak tari senantiasa melibatkan unsur anggota badan manusia. Unsur-unsur anggota badan di dalam membuat gerak tari bisa berdiri dengan sendiri, berhimpun maupun bersambungan. Suratmi (2019 : 20-21) menjelaskan macam macam seni tari yang ada di Indonesia dapat dibagi menjadi beberapa kelompok:

a) Tari Tradisional

Tari tradisional merupakan sebuah bentuk tarian yang sudah lama ada.Tarian ini diwariskan secara turun temurun. Sebuah tarian tradisional biasanya mengandung nilai filosofis,simbolis dan relegius. Semua aturan ragam gerak tari tradisional, formasi, busana, dan riasnya hingga kini tidak banyak berubah.

b) Tari Tradisiona Klasik

Tari tradisional klasik dikembangkan oleh para penari kalangan bangsawan istana. Aturan tarian biasanya baku atau tidak boleh diubah lagi. Gerakannya anggun dan busananya cenderung mewah. Fungsi tari tradisional klasik antara : sebagai sarana upacara adat atau penyambutan tamu kehormatan. Contoh : Tari Topeng Kelana (Jawa Barat), Bedhaya Srimpi (Jawa Tengah), SangHyang (Bali), Pakarena dan pajaga (Sulawesi Selatan).

c) Tari Tradisional Kerakyatan

Berkembang di kalangan rakyat biasa. Gerakannya cenderung mudah Ditarikan bersama juga iringan musik. Busananya relatif sederhana.Sering ditarikan pada saat perayaan sebagai tari pergaulan. Contoh : Jaipongan (Jawa Barat), payung (Melayu), Lilin (Sumatera Barat).

d) Tari Kreasi Baru

Merupakan tarian yang lepas dari standar tari yang baku. Dirancang menurut kreasi penata tari sesuai dengan situasi kondisi dengan tetap memelihara nilai artistiknya.Tari kreasi baik sebagai penampilan utama maupun sebagai tarian latar hingga kini terus berkembang dengan iringan musik yang bervariasi, sehingga muncul istilah tari modern. Pada garis besarnya tari kreasi dibedakan menjadi dua golongan yaitu:

1) Tari Kreasi Baru Berpolakan Tradisi

Yaitu tari kreasi yang garapannya dilandasi oleh kaidah-kaidah tari tradisi, baik dalam koreografi, musik/karawitan, rias dan busana, maupun tata teknik pentasnya.Walaupun ada pengembangan tidak menghilangkan esensi ketradisiannya.

2) Tari Kreasi Baru Tidak Berpolakan Tradisi (NonTradisi)

Tari Kreasi yang garapannya melepaskan diri dari pola-pola tradisi baik dalam hal koreografi, musik, rias dan busana, maupun tata teknik pentasnya.

Beetlestone (2012:3) mengemukakan dalam bukunya kreatifitas melibatkan pengungkapan atau pengekspresian gagasan dan perasaan serta penggunaan berbagai macam cara untuk melakukannya. Kreatifitas melibatkan pembuatan, menggunakan imajinasi, penciptaan, merangkai, mengarang, skill musik, pertunjukan, perencanaan, mengonstruksikan, membangun, skil-skil teknologis dan keluaran skala besar maupun skala kecil. Kreatifitas dapat dipandang sebagai sebuah bentuk intelejensi. Gardner dalam Beetlestone (2012:28). Memandang kreatifitas sebagai salah satu dari multipel intelejensi yang meliputi berbagai macam fungsi otak. Kreatifitas merupakan sebuah komponen penting dan memang perlu. Tanpa kreatifitas pelajar hanya akan bekerja pada sebuah tingkat kognitif yang sempit. Kreatifitas dan 
seni berkaitan erat melalui rangkaian representasi. Gagasan sebagian besar orang tentang kreatifitas seringkali dituangkan dalam bentuk gambar, lukisan, tarian serta permainan musik. Sebagian besar kreatifitas berada dalam kategori "seni" Beetlestone (2012:41). Menurut Beetlestone (2012:56) dalam bukunya mengemukakan mempertimbangkan tentang kreatifitas penting untuk membangun pemahaman bahwa semua anak memiliki hak yang sama untuk menjadi kreatif dan untuk memiliki akses penuh pada kesempatan dalam bidang-bidang kreatif dalam kurikulum mungkin kita tidak selalu memandang semua anak memiliki bakat yang setara terkait dengan kreatifitas dan mungkin menghubungkan semua ini dalam perbedaan dalam memandang pemikiran tentang kemampuan, kelas, ras, gender dan kekuatan fisik.

Tari adalah gerakan dari seluruh anggota tubuh yang selaras dengan bunyi musik,diatur oleh irama yang sesuai dengan maksud dan tujuan dalam tari. Ide garapan dapat muncul dari hasil apresiasi karya tari tradisi, kreasi, maupun modern, atau dasar pengalaman dalam kegiatan kehidupan dan aktivitas lainnya. menurut Suratmi (2019;43-36) Proses garap gerak tari banyak teknik dan cara yang dapat ditempuh pada saat melakukan proses pengembangan gerak tari. Proses garap gerak tari kreasi meliputi 4 tahap yaitu proses eksplorasi gerak, proses stilisasi dan seleksi gerak serta proses penggabungan gerak.

a. Proses Eksplorasi

Eksplorasi adalah proses penjajahan dan pencarian motif-motif gerak melalui berbagai cara yang dilakukan pada saat melakukan proses garap gerak tari. Pada langkah ekplorasi biasanya terbentuk karena adanya rangsang awal yang ditangkap oleh panca indera. Melalui rangsang inilah, praktik ide dan gagasan mengembangkan gerak dapat dilakukan dan akan mewujudkan proses kreatif gerak yang cenderung orisinal dari karya tari yang dibuat secara sederhana. Dalam proses eksplorasi ada beberapa stimulus yang dapat digunakan oleh penata tari dalam melakukan proses garap. Beberapa stimulus tersebut diantaranya berupa rangsangan auditif, visual, ideasional (gagasan) dan rangsang kinestetik. Jenis-jenis rangsangan tersebut antara lain:

1. Rangsangan Dengar (Auditif) adalah salah satu tahapan pengembangan gagasan gerak yang dilihat oleh suara atau bunyi suatu benda atau perbuatan sendiri. Contoh rangsang dengar antara lain suara instrumen musik (gendang, seruling, gamelan dan lainlain),suara manusia (nyanyian, puisi, tangisan, dan lain-lain), suara alam (gemuruh ombak, angin, kicauan burung dan lain-lain).

2. Rangsangan visual dapat muncul karena panca indera, rangsangan ini dapat timbul dari objek gambar, warna, wujud, patung, melihat orang menari atau bergerak, dan lain sejenisnya. Seorang penata tari melalui gambaran visual tersebut dapat mengambil gagasan/konsep yang ada dibalik hasil penglihatannya dan dengan segera mampu bereksplorasi menciptakan gerak tarian yang diinginkan.

3. Rangsangan Kinestetik dalam tahap ini dapat dilakukan seperti pada saat mengolah gerak berdasarkan pola hitungan.

4. Rangsangan Gagasan (idesional) adalah rangsangan yang seringkali digunakan peñata tari dalam membuat karyanya. Untuk menyampaikan gagasan atau cerita yang akan disajikan biasanya gerak dirangsang dan dibentuk dengan kapasitas kemampuan penata tari.

b. Stilasi GerakTari

Stilisasi adalah proses penghalusan, memberikan kesan indah dari suatu gerak. Dalam berkarya tari tentunya memerlukan bentuk-bentuk baru dari suatu gerak. Stilasi dilakukan pada hasil eksplorasi gerak untuk diubah/diperhalus dengan proses pengembangan. Proses pengembangan gerak ini dapat dilakukan dengan cara mengubah volume gerak, level, kesan, ragam gerak, struktur dan elemen lainnya.

c. Imrovisasi GerakTari

Improvisasi merupakan pengalaman secara spontanitas mencoba- coba/mencari-cari kemungkinan ragam gerak yang telah diperoleh waktu improvisasi. Inti dari gerak 


\section{PAEDAGOGY : Jurnal Ilmu Pendidikan dan Psikologi \\ Vol. 1 No. 1 Juni 2021 e-ISSN : 2797-3344 P-ISSN : 2797-3336}

improvisasi adalah bentuk-bentuk gerak yang dilakukan penari yang pada setiap saat dapat dilakukan berbeda tetapi masih disesuaikan dengan maksud pengadegan dari gerak itu sendiri.

d. Komposisi Tari

Membuat penataan tari atau mengkomposisikan tari memerlukan kreativitas yang berhubungan dengan kemampuan berpikir menyangkut sikap dan perasaan seseorang. Kreativitas memerlukan kelancaran, keluwesan (fleksibilitas), orisinalitas berpikir, serta kemampuan untuk mengelaborasi (mengembangkan, memperkaya, memperinci) suatu gagasan. Dengan demikian, orang kreatif ialah orang yang menggunakan imajinasinya untuk memecahkan persoalan. Temuan gerakan dan cara penyusunan ke dalam tarian secara bertahap telah dilambangkan melalui improvisasi dan eksplorasi.

\section{Audio Visual}

Bahri, Zain (2010: 124) mengemukakan bahwa media audio visual merupakan jenis media yang selain mengandung unsur suara juga mengandung unsur gambar yang bisa dilihat, misalnya rekaman video, berbagai ukuran film, slide suara, dan lain sebagainya. Media audio visual dapat dikatakan seperangkat alat yang melibatkan indra dan organ tubuh seperti telinga (audio), mata (visual) dan tangan (kinetik) yang memberikan informasi atau pesan yang mudah dimengerti berupa gambar dalam bentuk video dan musik. Video bersifat interaktif tutorial membimbing siswa untuk memahami sebuah materi melalui visualisasi. Media ini dibagi lagi ke dalam :

1. Audiovisual Diam, yaitu media yang menampilkan suara dan gambar diam seperti film bingkai suara (sound slides), film rangkai suara, dan cetak suara.

2. Audiovisual gerak, yaitu media yang dapat menampilkan unsur suara dan gambar yang bergerak seperti film suara dan video-cassette.

Pembagian lain dari media ini adalah :

a. Audiovisual Murni, yaitu bai unsur suara maupun unsur gambar berasal dari satu sumber seperti film video-cassette, dan

b. Audiovisual Tidak Murni, yaitu yang unsur suara dan unsur gambar nya berasal dari sumber yang berbeda, misalnya film bingkai suara yang unsur gambarnya bersumber dari slides proyektor dan unsur suaranya bersumber dari tape recorder. Contoh lainnya adalah film strip suara dan cetak suara.

Diharapkan dengan adanya pemutaran video siswa dapat memahami dan mengamati tentang konsep karya tari kreasi sehingga mereka bisa berkreasi dalam menciptakan suatu gerakan.

\section{METODE PENELITIAN}

Metode yang digunakan dalam pelaksanaan Best Pactice ini adalah menerapkan pembelajaran dengan model pembelajaran Problem Based Learning (PBL). Adapun tahapan kegiatannya adalah awal pembelajaran menggunakan model konvensional kemudian pada tahap ke dua baru menngunakan pendekatan Problem Based Learning. Prosedur penelitian yang digunakan yaitu : a) perencanaan, b) tindakan kelas , c) pengamatan, d) refleksi. Best Pactice ini dilaksanakan selama dua bulan, dari bulan Januari sampai Februari 2020 bertempat di kelas IXG dan IXA SMP Negeri 1 Pecalungan. Subyek penelitian Best Practice ini adalah siswa kelas IXG sebanyak 29 siswa dan IXA sebanyak 32 SMP Negeri 1 Pecalungan Tahun Pelajaran 2019/2020. Bahan yang digunakan dalam Best Pactice ini adalah materi seni budaya (seni tari) kelas IX semester 2 tentang memeragakan tari kreasi. Data yang diambil selama penelitian diperoleh dengan cara melakukan observasi, wawancara, dokumentasi dan tes. Permasalahan yang diteliti adalah peningkatkan Apresiasi Konsep Karya Tari Berbantuan Media Rekaman Audio Visual Pada Siswa Kelas IX Semester 2 SMP Negeri 1 Pecalungan 
Tahun Pelajaran 2019/2020. Data yang digunakan dalam penelitian ini adalah hasil observasi dan pengamatan serta wawancara. Sedangkan untuk sumber data penulis kumpulkan dari berbagai sumber yaitu : Informan guru dan siswa serta Catatan observasi /pengamatan. Pelaksanaan dilaksanakan 4 kali pertemuan yaitu pada hari Jum'at, 24 Januari 2020; Senin, 27 Januari 2020; Jum'at, 7 Februari 2020 ; Senin, 10 Februari 2020;. Kegiatan pembelajaran dilaksanakan dengan mengacu Sintak Problem Based Learning

\section{Prosedur Penelitian}

Prosedur penelitian yang digunakan yaitu : a) perencanaan (planning), b) tindakan kelas (acting), c) pengamatan (observing), d) refleksi (reflecsing), yang pada pelakasanaannya keempat komponen kegiatan pokok itu berlangsung secara terus menerus dengan diselipkan modifikasi pada komponen perencanaan berupa perbaikan perencanaan. Model pelaksanaan penelitian Best Practice ini adalah sebagi berikut:

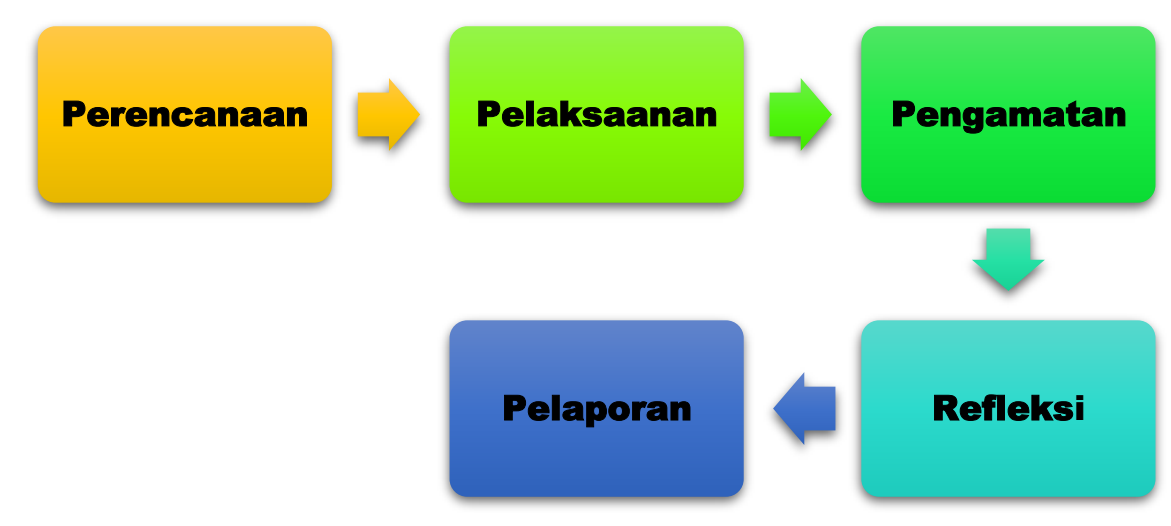

Gambar 1 : Bagan Prosedur Penelitian

Terdapat empat tahapan dalam prosedur penelitian ini, (1) Perencanaan (Planing), kegiatannya Identifikasi masalah, banyaknya siswa yang tidak tuntas belajar materi sebelumnya yaitu ketika guru masih menggunakan cara konvensional; (2) Pelaksanaan Tindakan (Acting), guru melakukan penelitian dengan model pembelajaran inovatif, yang menuntut siswa belajar secara aktif melalui model pembelajan PBL. Guru sebagai narasumber, dan memandu penarikan kesimpulan; (3) Pemantauan (Observasi), pemantauan atau pengamatan dilakukan dikelas pada saat berlangsungnya proses belajar mengajar juga dilingkungan sekolah dengan cara membuat catatan-catatan dalm buku observasi. Refleksi merupakan kegiatan yang mengupas keberhasilan atau perubahan perubahan yang terjadi setelah diterapkan model pembelajaran PBL pada Apresiasi Konsep Karya Tari Berbantuan Media Rekaman Audio Visual, sedang kegiatan proses penelitian sebagai berikut : (1) Menetapkan Pelaksanaan Tindakan selama 4 pertemuan; (2) Menyusun rencana pelaksanaan pembelajaran (RPP); (3) Menyiapkan sumber belajar berupa materi diskusi berupa Lembar Kerja Siswa, Video Pembelajaran Tari Kreasi, dan Buku Seni Budaya IX; (4) Menyiapkan instrumen penelitian untuk siswa yang meliputi instrumen penilaian kemampuan kognitif, instrumen penilaian psikomotorik berupa lembar penilaian karya siswa.; (5) Menyiapkan alat evaluasi berupa persentasi hasil eksplorasi masing-masing kelompok. Khususnya pada penyusunan rencana pelaksanaan pembelajaran, peneliti mendesain sintak pembelajaran $P B L$ sedemikian rupa sehingga peningkatan apresiasi konsep karya tari berbantuan media rekaman audio visual dilaksanakan secara tepat. 


\section{HASIL DAN PEMBAHASAN}

1. Pemetaan KD

\begin{tabular}{|l|l|}
\hline \multicolumn{2}{|l|}{ KD Pengetahuan } \\
\hline 3.1 & $\begin{array}{l}\text { Memahami keunikan gerak tari kreasi berdasarkan unsur } \\
\text { pendukung tari }\end{array}$ \\
\hline KD Ketrampilan \\
\hline & $\begin{array}{l}\text { Meragakan keunikan gerak tari kreasi berdasarkan unsur } \\
\text { pendukung tari }\end{array}$ \\
\hline
\end{tabular}

2. Analisis Target Kompetensi

Hasil analisis target kompetensinya adalah sebagai berikut:

\begin{tabular}{|l|l|l|}
\hline \multicolumn{2}{|l|}{ KD Pengetahuan } \\
\hline 3.1 & $\begin{array}{l}\text { Memahami keunikan gerak tari kreasi } \\
\text { berdasarkan unsur pendukung tari }\end{array}$ & $\begin{array}{l}\text { Menjelaskan gerak tari kreasi } \\
\text { berdasarkan unsur pendukung tari }\end{array}$ \\
\hline KD Ketrampilan \\
\hline 4.1 & $\begin{array}{l}\text { Meragakan keunikan gerak tari kreasi } \\
\text { berdasarkan unsur pendukung tari }\end{array}$ & $\begin{array}{l}\text { Melakukan gerak tari kreasi } \\
\text { berdasarkan unsur pendukung tari }\end{array}$ \\
\hline
\end{tabular}

3. Perumusan Indikator Pencapaian Kompetensi

\begin{tabular}{|c|c|c|}
\hline No & KOMPETENSI DASAR & INDIKATOR PENCAPAIAN KOMPETENSI \\
\hline & $\begin{array}{l}\text { Kompetensi Pengetahuan: } \\
\text { 3.1 } \text { Menganalisis keunikan } \\
\text { gerak tari kreasi } \\
\text { berdasarkan unsur } \\
\text { pendukung tari }\end{array}$ & 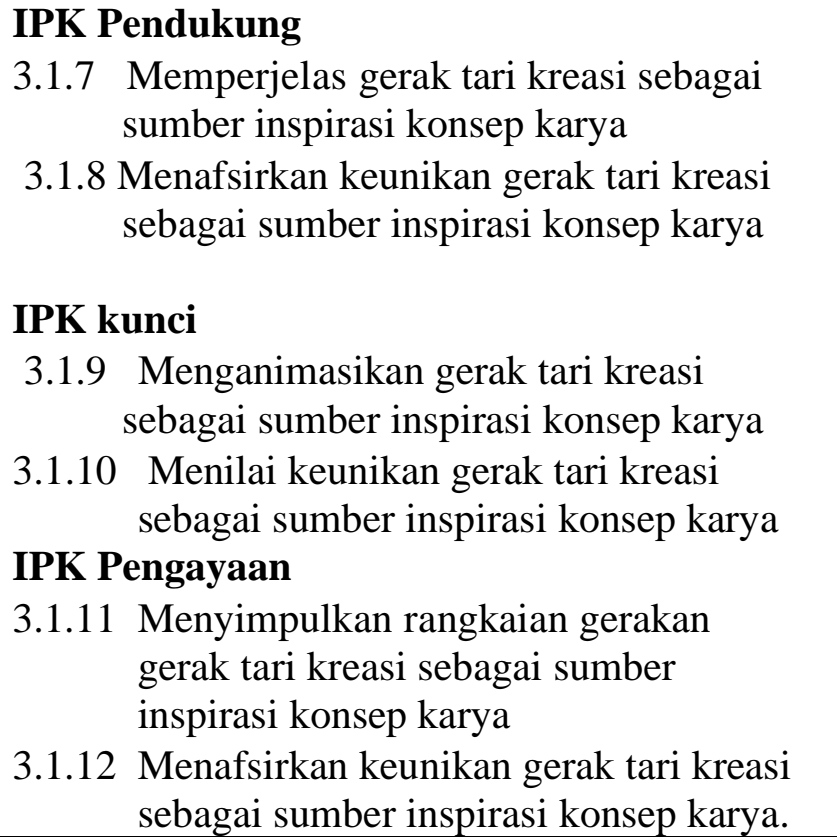 \\
\hline & $\begin{array}{l}\text { Kompetensi Keterampilan: } \\
\text { 4.1 Mentransfer keunikan gerak } \\
\text { tari kreasi berdasarkan unsur } \\
\text { pendukung tari }\end{array}$ & $\begin{array}{l}\text { IPK Pendukung } \\
\text { 4.1.7 } \begin{array}{l}\text { Menggabungkan rangkaian gerak tari } \\
\text { kreasi sebagai sumber inspirasi konsep } \\
\text { karya }\end{array} \\
\text { 4.1.8 } \\
\begin{array}{l}\text { Mengkode keunikan gerak tari kreasi } \\
\text { sebagai sumberinspirasi konsep karya. }\end{array} \\
\text { IPK Kunci } \\
\text { 4.1.9 Membuktikan rangkaian gerak tari } \\
\begin{array}{l}\text { kreasi sebagai sumber inspirasi konsep } \\
\text { karya }\end{array} \\
\text { 4.1.10 } \\
\text { Menafsirkan keunikan gerak tari kreasi } \\
\text { sebagai sumber inspirasi konsep karya }\end{array}$ \\
\hline
\end{tabular}




\begin{tabular}{|l|l|}
\hline IPK Pengayaan \\
4.1 .11 & $\begin{array}{l}\text { Memvalidasi rangkaian gerakan gerak } \\
\text { tari kreasi sebagai sumber inspirasi } \\
\text { konsep karya }\end{array}$ \\
$4.1 .12 \begin{array}{l}\text { Mengoreksi keunikan gerak tari kreasi } \\
\text { sebagai sumber inspirasi konsep karya. }\end{array}$ \\
\hline
\end{tabular}

4. Pemilihan Model pembelajaran

Model pembelajaran yang dipilih adalah Problem Based Learning (PBL)

5. Merencanakan kegiatan pembelajaran sesuai dengan Model Pembelajaran

Pengembangan desain pembelajaran dilakukandengan merinci kegiatan pembelajaran yang dilakukan sesuai sintak Problem Based Learning.

Berikut adalah rencana pembelajaran yang dikembangkan berdasarkan model Problem Based Learning

\begin{tabular}{|c|c|c|}
\hline $\begin{array}{l}\text { Sintak Model } \\
\text { Pembelajaran }\end{array}$ & Guru & Siswa \\
\hline $\begin{array}{l}\text { Pertemuan } 1 \text { dan } 2 \\
\text { Pertanyaan } \\
\text { mendasar }\end{array}$ & $\begin{array}{l}\text { Guru memberikan pertanyaan pada } \\
\text { siswa tentang gerak tari } \\
\text { kreasi/modern berdasarkan unsur } \\
\text { pendukung, dan mempersilahkan } \\
\text { siswa untuk menjawab sesuai dengan } \\
\text { tingkat pengetahuan mereka tentang } \\
\text { gerak tari kreasi/modern berdasarkan } \\
\text { unsur pendukung }\end{array}$ & $\begin{array}{l}\text { Siswa menjawab pertanyaan tentang } \\
\text { gerak tari kreasi/modern berdasarkan } \\
\text { unsur pendukung, r dan } \\
\text { mempersilahkan siswar untuk } \\
\text { menjawab sesuai dengan tingkat } \\
\text { pengetahuan mereka tentang gerak } \\
\text { tari kreasi/modern berdasarkan unsur } \\
\text { pendukung }\end{array}$ \\
\hline $\begin{array}{l}\text { Mendesain } \\
\text { perencanaan } \\
\text { produk }\end{array}$ & $\begin{array}{l}\text { Guru membagi siswa SMP kelas IX } \\
\text { menjadi } 8 \text { kelompok. } \\
\text { Guru mendampingi masing-masing } \\
\text { kelompok membuat komitmen untuk } \\
\text { bekerja sama yang diwujudkan dalam } \\
\text { bentuk berbagi tugas yang seimbang } \\
\text { antar siswa }\end{array}$ & $\begin{array}{l}\text { Siswa membentuk kelompok menjadi } \\
8 \text { kelompok. } \\
\text { Masing-masing kelompok membuat } \\
\text { komitmen untuk bekerja sama yang } \\
\text { diwujudkan dalam bentuk berbagi } \\
\text { tugas yang seimbang antar siswa }\end{array}$ \\
\hline $\begin{array}{l}\text { Menyusun jadwal } \\
\text { pembuatan }\end{array}$ & $\begin{array}{l}\text { Mendampingi } r \text { masing-masing } \\
\text { kelompok menyusun strategi dan cara } \\
\text { kerja eksplorasi tentang memahami } \\
\text { keunikan gerak tari kreasi/modern } \\
\text { dengan menggunakan buku seni } \\
\text { budaya kelas } 9 \text { halaman } 75-87 \text { yang } \\
\text { membahas pengertian, jenis, fungsi } \\
\text { dan nilai estetis tari kreasi/modern. }\end{array}$ & $\begin{array}{l}\text { Masing-masing kelompok menyusun } \\
\text { strategi dan cara kerja eksploras } \\
\text { tentang memahami keunikan gerak } \\
\text { tari kreasi/modern dengan } \\
\text { menggunakan buku seni budaya kelas } \\
9 \text { halaman } 75-87 \text { yang membahas } \\
\text { pengertian, jenis, fungsi dan nilai } \\
\text { estetis tari kreasi/modern. }\end{array}$ \\
\hline $\begin{array}{l}\text { Memonitoring } \\
\text { keaktifan dan } \\
\text { perkembangan } \\
\text { proyek }\end{array}$ & $\begin{array}{l}\text { Guru memposisikan diri sebagai } \\
\text { mentor dan mendampingi kelompok } \\
\text { siswa Kelas IX dalam melaksanakan } \\
\text { ekplorasi tentang merangkai gerak tari } \\
\text { kreasi/modern berdasarkan unsur } \\
\text { pendukung tari. }\end{array}$ & $\begin{array}{l}\text { Dengan didampingi guru kelompok } \\
\text { siswa Kelas IX melaksanakan } \\
\text { ekplorasi tentang merangkai gerak } \\
\text { tari kreasi/modern berdasarkan unsur } \\
\text { pendukung tari. }\end{array}$ \\
\hline Menguji hasil & $\begin{array}{l}\text { Guru menjadi fasilitator masing- } \\
\text { masing siswa dslsm mendiskusikan } \\
\text { alokasi waktu penyelesaian mengenai } \\
\text { tugas eksplorasi tentang merangkai }\end{array}$ & $\begin{array}{l}\text { Masing-masing siswa mendiskusikan } \\
\text { alokasi waktu penyelesaian mengenai } \\
\text { tugas eksplorasi tentang merangkai } \\
\text { gerak tari kreasi/modern berdasarkan } \\
\text { unsur pendukung tari. }\end{array}$ \\
\hline
\end{tabular}




\begin{tabular}{|c|c|c|}
\hline & $\begin{array}{l}\text { gerak tari kreasi/modern berdasarkan } \\
\text { unsur pendukung tari. }\end{array}$ & \\
\hline $\begin{array}{l}\text { Evaluasi } \\
\text { pengalaman } \\
\text { belajar }\end{array}$ & $\begin{array}{l}\text { Meminta masing-masing siswa dalam } \\
\text { kelompoknya untuk mengumpulkan } \\
\text { dan mendiskusikan hasil eksplorasi } \\
\text { para anggotanya untuk menjadi } \\
\text { rencana susunan gerakan tari tentang } \\
\text { merangkai gerak tari kreasi/modern } \\
\text { berdasarkan unsur pendukung tari }\end{array}$ & $\begin{array}{l}\text { Masing-masing siswa kelas IX dalam } \\
\text { kelompoknya mengumpulkan dan } \\
\text { mendiskusikan hasil eksplorasi para } \\
\text { anggotanya untuk menjadi rencana } \\
\text { susunan gerakan tari tentang } \\
\text { merangkai gerak tari kreasi/modern } \\
\text { berdasarkan unsur pendukung tari }\end{array}$ \\
\hline $\begin{array}{l}\text { Pertemuan } 3 \text { dan } 4 \\
\text { Pertanyaan } \\
\text { mendasar }\end{array}$ & $\begin{array}{l}\text { Guru memberikan kesempatan pada } \\
\text { siswa mendemonstrasikan rangkaian } \\
\text { gerak tari kreasi sebagai sumber } \\
\text { inspirasi konsep karya sesuai dengan } \\
\text { ketrampilan yang dimiliki siswa. }\end{array}$ & $\begin{array}{l}\text { siswa mendemonstrasikan rangkaian } \\
\text { gerak tari kreasi sebagai sumber } \\
\text { inspirasi konsep karya sesuai dengan } \\
\text { ketrampilan yang dimiliki siswa. }\end{array}$ \\
\hline $\begin{array}{l}\text { Mendesain } \\
\text { perencanaan } \\
\text { produk }\end{array}$ & $\begin{array}{l}\text { Guru membimbing masing-masing } \\
\text { siswa kelas IX dalam kelompoknya } \\
\text { Menirukan rangkaian gerak tari kreasi } \\
\text { sebagai sumber inspirasi konsep karya } \\
\text { hasil eksplorasi para anggotanya } \\
\text { untuk menjadi rencana susunan } \\
\text { gerakan tari tentang merangkai gerak } \\
\text { tari kreasi/modern berdasarkan unsur } \\
\text { pendukung tari }\end{array}$ & $\begin{array}{l}\text { Masing-masing siswa kelas IX dalam } \\
\text { kelompoknya Menirukan rangkaian } \\
\text { gerak tari kreasi sebagai sumber } \\
\text { inspirasi konsep karya hasil } \\
\text { eksplorasi para anggotanya untuk } \\
\text { menjadi rencana susunan gerakan tari } \\
\text { tentang merangkai gerak tari } \\
\text { kreasi/modern berdasarkan unsur } \\
\text { pendukung tari. } \\
\text { Menyimak tayangan video. } \\
\text { Membuat catatan penting sesuai } \\
\text { dengan tugas yang harus dikerjakan }\end{array}$ \\
\hline $\begin{array}{l}\text { Menyusun jadwal } \\
\text { pembuatan }\end{array}$ & $\begin{array}{l}\text { Guru memfasilitasi masing-masing } \\
\text { kelompok menyusun strategi dan cara } \\
\text { kerja mendemonstrasikan rangkaian } \\
\text { gerak tari kreasi sebagai sumber } \\
\text { inspirasi konsep karya. }\end{array}$ & $\begin{array}{l}\text { Masing-masing kelompok menyusun } \\
\text { strategi dan cara kerja } \\
\text { mendemonstrasikan rangkaian gerak } \\
\text { tari kreasi sebagai sumber inspirasi } \\
\text { konsep karya. }\end{array}$ \\
\hline $\begin{array}{l}\text { Memonitoring } \\
\text { keaktifan dan } \\
\text { perkembangan } \\
\text { proyek }\end{array}$ & $\begin{array}{l}\text { Guru memposisikan diri sebagai } \\
\text { mentor dan mendampingi kelompok } \\
\text { siswa Kelas IX dalam melaksanakan } \\
\text { eksplorasi tentang merangkai gerak } \\
\text { tari kreasi/modern sebagai sumber } \\
\text { inspirasi konsep karya. }\end{array}$ & $\begin{array}{l}\text { Dengan pendampingan guru, } \\
\text { kelompok siswa Kelas IX } \\
\text { melaksanakan eksplorasi tentang } \\
\text { merangkai gerak tari kreasi/modern } \\
\text { sebagai sumber inspirasi konsep } \\
\text { karya. }\end{array}$ \\
\hline Menguji hasil & $\begin{array}{l}\text { Guru menjadi fasilitator masing- } \\
\text { masing siswa mendiskusikan alokasi } \\
\text { waktu penyelesaian mengenai tugas } \\
\text { mendemonstrasikan rangkaian gerak } \\
\text { tari kreasi sebagai sumber inspirasi } \\
\text { konsep karya }\end{array}$ & $\begin{array}{l}\text { Masing-masing siswa mendiskusikan } \\
\text { alokasi waktu penyelesaian mengenai } \\
\text { tugas mendemonstrasikan rangkaian } \\
\text { gerak tari kreasi sebagai sumber } \\
\text { inspirasi konsep karya. } \\
\text { Menyusun laporan hasil kerja } \\
\text { kelompok. } \\
\text { Mempresentasikan hasil kerja } \\
\text { kelompok di depan kelas } \\
\text { Kelompok lain mengajukan } \\
\text { pertanyaan dan usulan terhadap hasil } \\
\text { presentasi kelompok }\end{array}$ \\
\hline
\end{tabular}




\begin{tabular}{|l|l|lr|}
\hline Evaluasi & Guru meminta masing-masing siswa & Masing-masing siswa kelas IX dalam \\
pengalaman & kelas IX dalam kelompoknya & kelompoknya mengumpulkan dan \\
belajar & mengumpulkan dan mendiskusikan & mendiskusikan hasil eksplorasi para \\
& hasil eksplorasi para anggotanya & anggotanya mendemonstrasikan \\
mendemonstrasikan rangkaian gerak & rangkaian gerak tari kreasi sebagai \\
& tari kreasi sebagai sumber inspirasi & sumber inspirasi konsep karya. \\
konsep karya. & Menyimak penjelasan guru. \\
& & Mengajukan pertanyaan dan atau \\
& tanggapan bila belum paham. \\
\hline
\end{tabular}

6. Penyusunan Perangkat Pembelajaran

Berdasarkan hasil kerja 1 hingga 5 diatas kemudian disusun perangkat pembelajaran meliputi RPP, bahan ajar dan LKS, instrumen penilaian. RPP disusun dengan mengintegrasikan kegiatan literasi, penguatan pendidikan karakter (PPK) dan kecakapan abad 21.

\section{Alat/instrumen}

Media pembelajaran yang digunakan dalam Best Practice ini adalah (a) Buku teks Seni Budaya kelas IX tahun 2018 (b) buku teks Seni Tari Pengetahuan Praktis Bagi Guru Seni Tari tahun 2005 (c) buku teks Program Pengembangan Keprofesian Berkelanjutan melalui Pengembangan Kompetensi Pembelajaran berbasis Zonasi SMP mapel Seni Budaya tahun 2019 (d) Video Tari Nusantara (e) Video Tari Mancanegara. Instrumen yang digunakan dalam Best Practice ini adalah (a) instrumen untuk mengamati proses pembelajaran berupa lembar observasi dan (b) instrumen untuk melihat hasil belajar siswa dengan menggunakan (1) tes tertulis (uraian) dan (2) tes praktek.

Proses pembelajaran seni budaya (seni tari) Konsep Karya Tari yang dilakukan dengan menerapkan model pembelajaran Problem Based Leraning berlangsung aktif. Siswa menjadi lebih aktif merespon pertanyaan dari guru, termasuk mengajukan pertanyaan pada guru maupun temannya. Aktifitas pembelajaran yang dirancang sesuai sintak Problem Based Leraning mengharuskan siswa aktif selama proses pembelajaran. Pembelajaran seni budaya (seni tari) Konsep Karya Tari yang dilakukan dengan menerapkan model pembelajaran Problem Based Leraning meningkatkan kemampuan siswa dalam melakukan transfer knowledge. Setelah membaca, meringkas, mendiskusikan buku teks dan menyaksikan video tari Nusantara serta tari Mancanegara, siswa tidak hanya memahami pengetahuan konseptual dan pengetahuan prosedural, tetapi juga memahami konsep apresiasi dan berkarya tari. Penerapan model pembelajaran Problem Based Leraning meningkatkan kemampuan siswa untuk berpikir kritis. Hal ini dapat dilihat dari tingkat partisipasi siswa untuk bertanya dan menanggapi apresiasi dan konsep berkarya tari. Dalam pembelajaran sebelumnya yang dilakukan penulis tanpa berorientasi High Order Thinking Skill suasana kelas cenderung sepi karena siswa pasif dan terlalu serius. Siswa cenderung bekerja sendiri-sendiri untuk berlomba menyelesaikan tugas yang diberikan guru. Fokus guru adalah bagaimana siswa dapat menyelesaikan soal yang disajikan, tanpa memperdulikan pada proses berpikir siswa. Materi pembelajaran yang selama ini selalu disajikan dengan pola deduktif (diawali ceramah teori tentang materi yang dipelajari, pemberian tugas dan pembahasan), membuat siswa cenderung menghapalkan teori. Berbeda kondisinya dengan Best Pactice pembelajaran seni budaya (seni tari) Konsep Karya Tari yang berorientasi High Order Thinking Skill dengan menerapkan Problem Based Leraning, dalam pembelajaran ini pemahaman siswa tentang konsep karya tari benar-benar dibangun oleh siswa melalui pengamatan dan diskusi yang menuntut kemampuan siswa untuk berpikir kritis. Penerapan model pembelajaran Problem Based Leraning juga meningkatkan kemampuan siswa dalam memecahkan masalah (problem solving). Problem Based Leraning yang diterapkan dengan menyajikan teks tulis dan video berisi permasalahn kontekstual mampu mendorong siswa merumuskan pemecahan masalah. Sebelum menerapkan Problem Based Leraning, 
penulis melaksanakan pembelajaran sesuai dengan buku guru dan buku siswa. Meskipun permasalahan yang disajikan dalam buku teks kadang kurang sesuai dengan kehidupan seharihari siswa, tetap saja penulis pergunakan. Dengan menerapkan Problem Based Leraning, siswa tidak hanya belajar dari buku teks tulis, tetapi juga dari video serta diberikan kesempatan terbuka untuk mencari data, materi dari sumber lainnya.

\section{Masalah yang Dihadapi}

Masalah yang dihadapi terutama adalah siswa belum terbiasa belajar dengan model Problem Based Leraning. Masalah berikutnya adalah kepercayaan diri siswa yang masih kurang pada model pembelajaran Problem Based Leraning karena siswa terbiasa mendapat penjelasan guru melalui ceramah. Masalah lainnya adalah terbatasnya akses internet di sekolah, sehingga siswa tidak mempunyai banyak kesempatan untuk mencari sumber belajar secara online

\section{Cara mengatasi Masalah}

Memberikan morivasi pada siswa agar lebih percaya diri dengan model pembelajaran Problem Based Leraning dapat membantu mereka lebih menguasai materi pembelajaran, lebih berpikir kritis dan manfaat belajar berorientasi pada ketrampilan berpikir tingkat tinggi (High Order Thinking Skill). Siswa diberikan kesempatan untuk browsing materi pembelajaran sesuai dengan KD yang dipelajari dengan menggunakan fasililas HP dan internet, sehingga dapat meningkatkan literasi digital siswa.

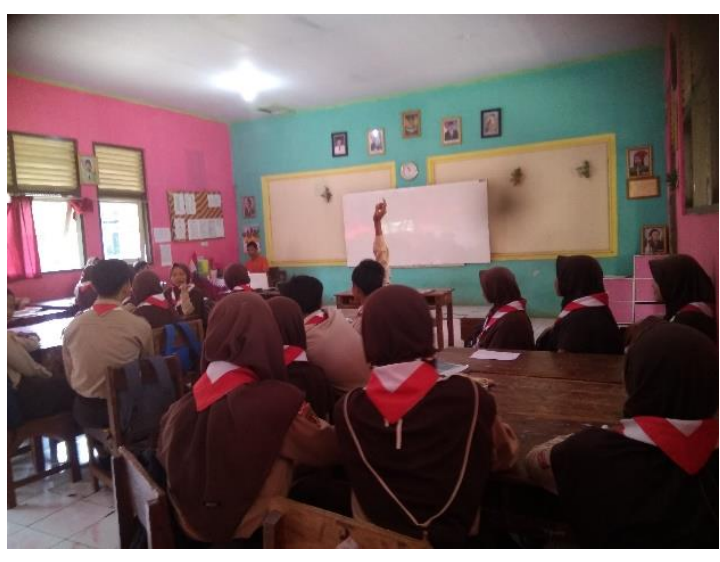

Poto 1. Kegiatan Pendahuluan

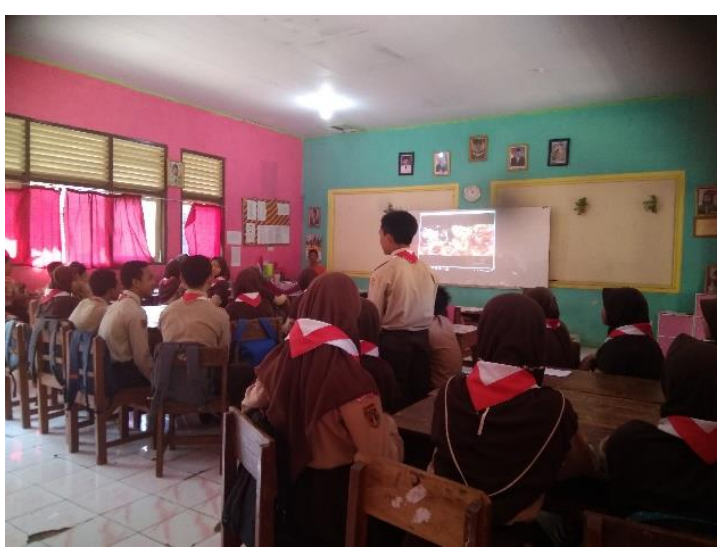

Poto 3. Critical Thinking Creativity

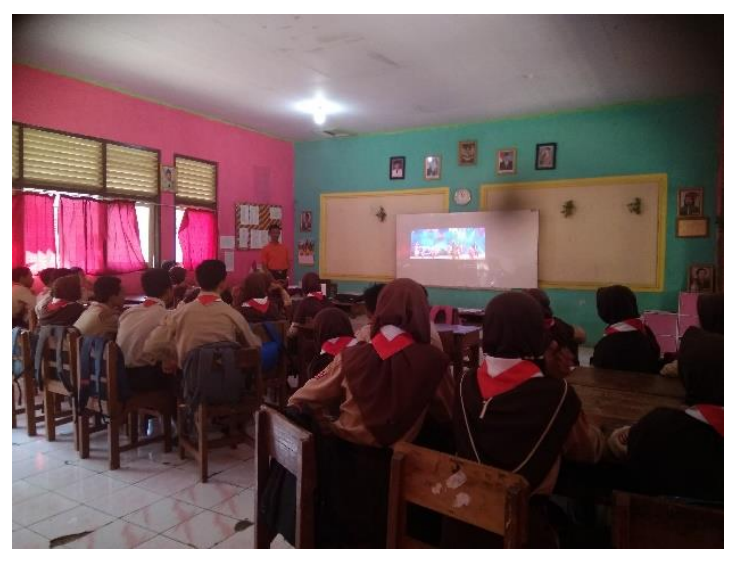

Poto 2. Proses Saintifik

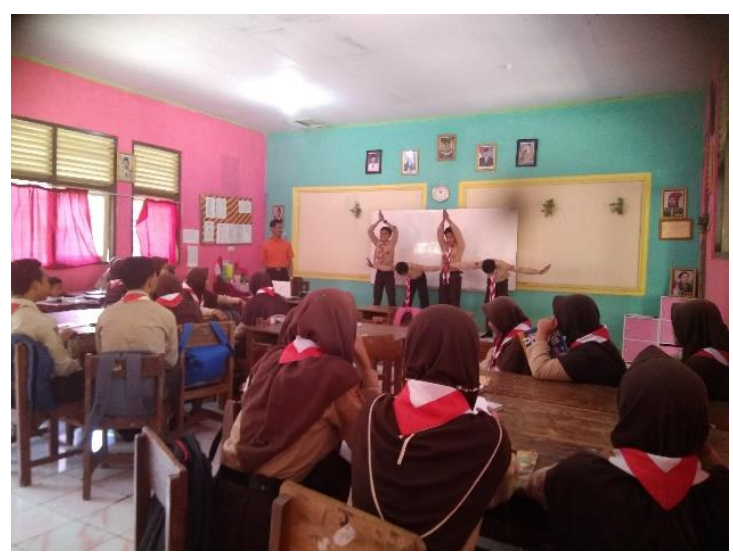

Poto 4. Problem Solving 
Vol. 1 No. 1 Juni 2021 e-ISSN : 2797-3344 P-ISSN : 2797-3336

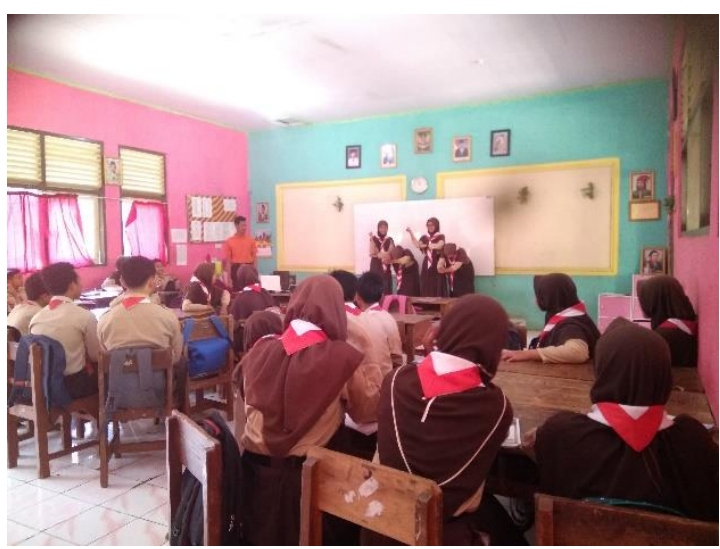

Poto 5. Kegiatan Penilaian

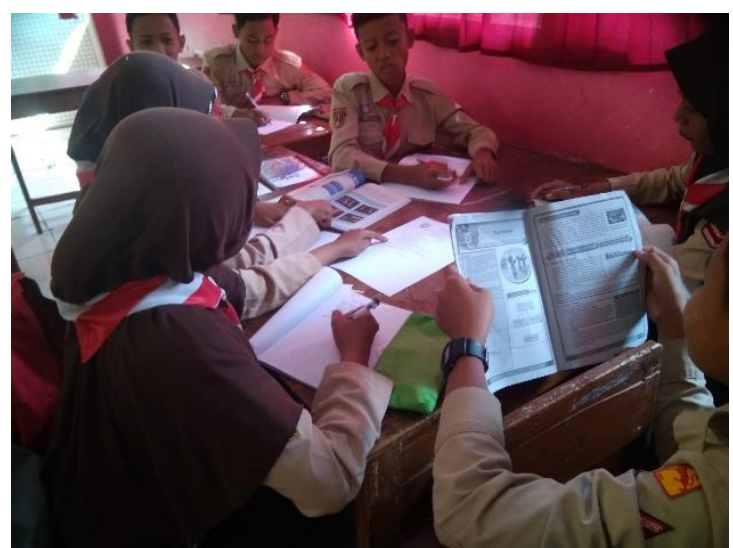

Poto 6. Dimensi Pengetahuan

Gambar 2. Pembelajaran Pertama dan kedua

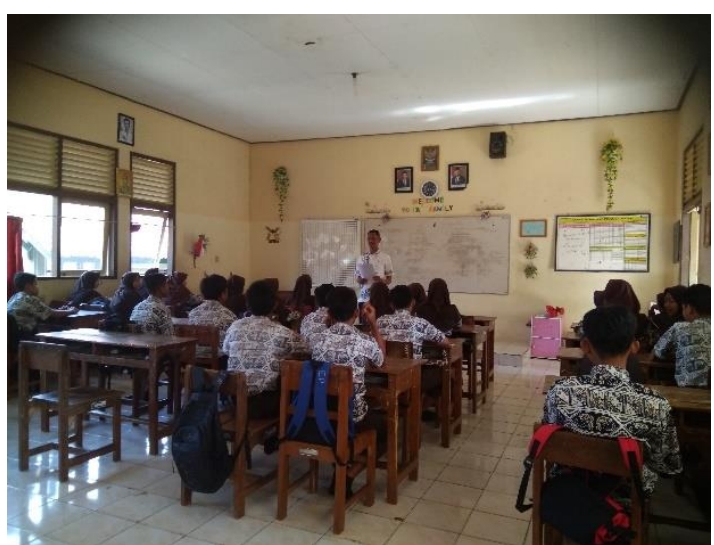

Poto 7. Transfer Knowledge

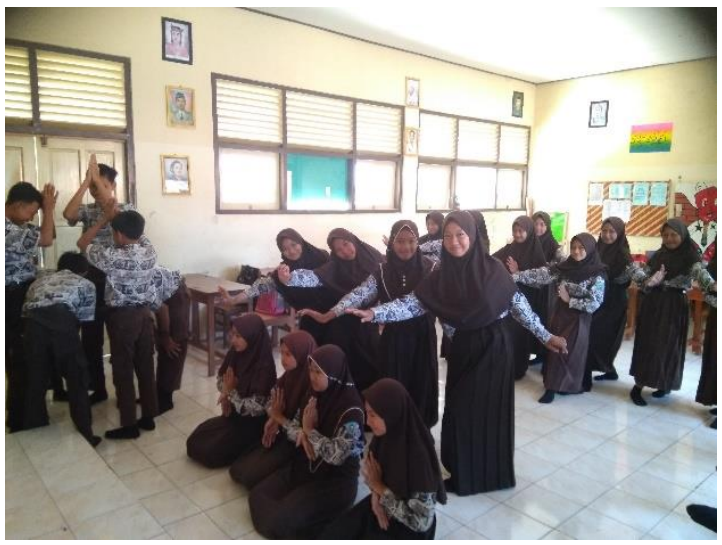

Poto 9. Problem Solving

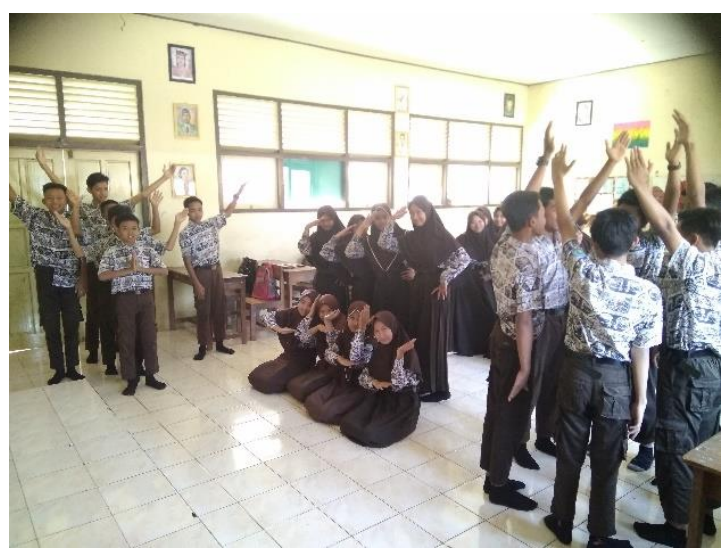

Poto 8. Critical Thinking Creativity

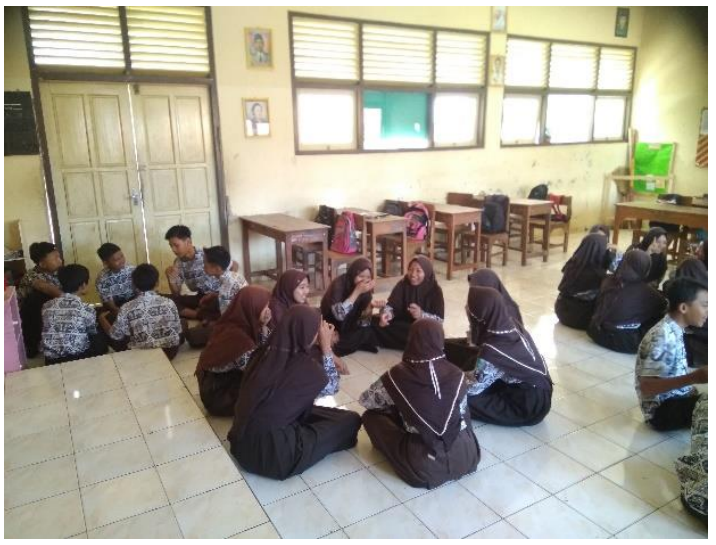

Poto 10. Dimensi Pengetahuan 


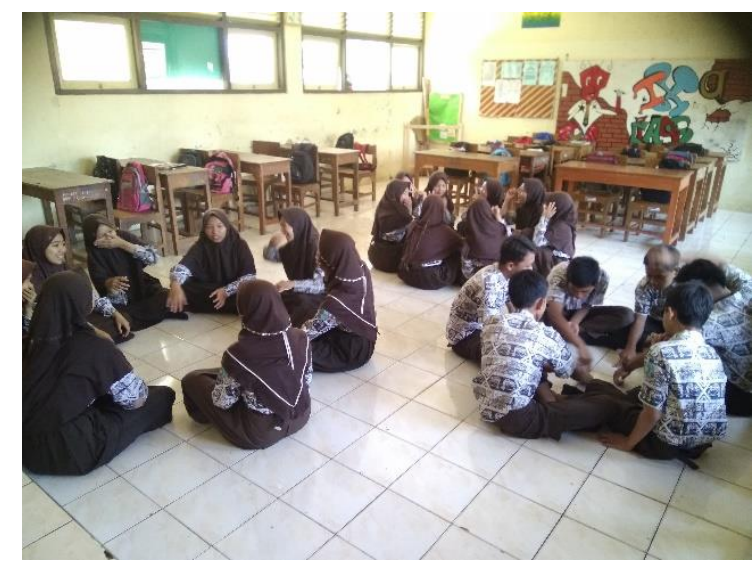

Poto 11. Dimensi Pengetahuan

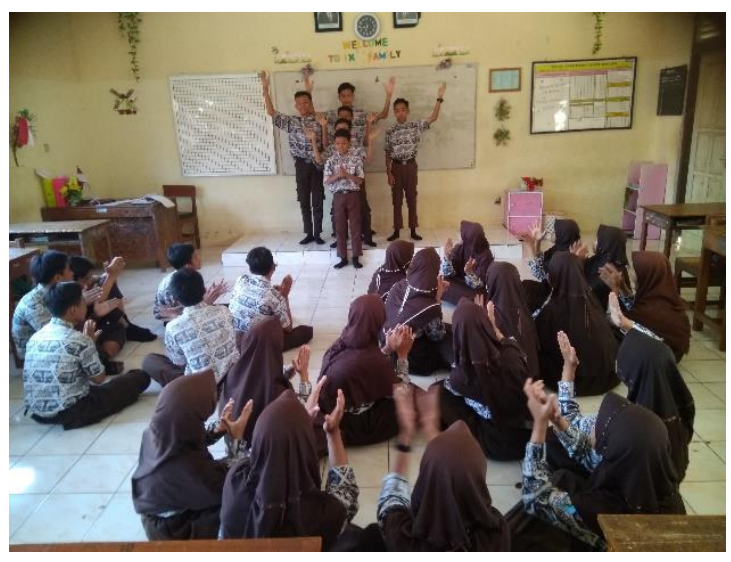

Poto 13. Kegiatan Penilaian

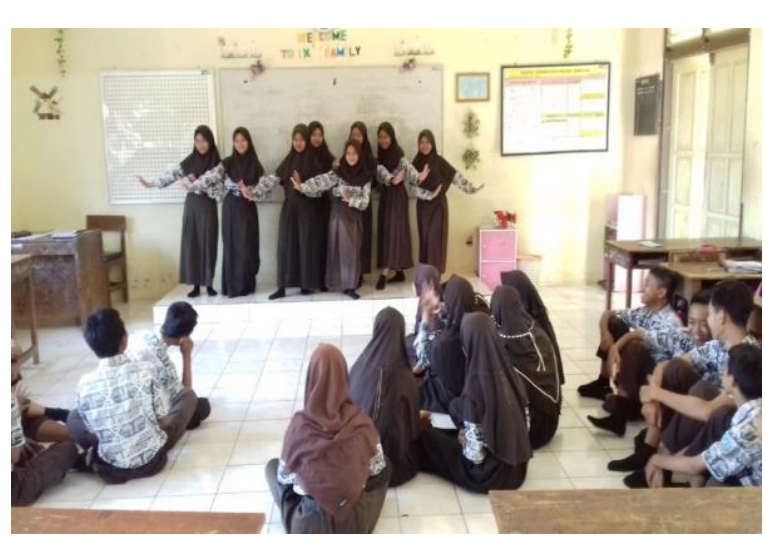

Poto 12. Kecakapan Abad 21

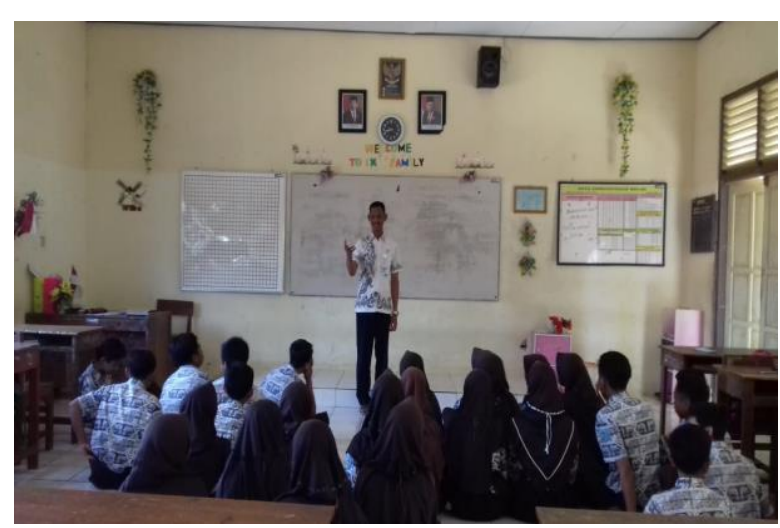

Poto 14. Kegiatan Penutup

Gambar 3. Pembelajaran Ketiga dan keempat

\section{KESIMPULAN DAN SARAN}

Berdasarkan uraian diatas dapat ditarik kesimpulan sebagai berikut: ada peningkatan yang signifikan pada Apresiasi Konsep Karya Tari Berbantuan Media Rekaman Audio Visual dengan model pembelajaran Problem Based Learning dalam pembelajaran berorientasi High Order Thinking Skill, karena dapat meningkatkan kemampuan siswa dalam melakukan transfer pengetahuan, berpikir kritis dan pemecahan masalah. Dengan penyusunan rencana pelaksanaan pembelajaran (RPP) secara sistematis dan cermat, pembelajaran seni budaya(seni tari) Konsep Karya Tari dengan model pembelajaran Problem Based Learning yang dilaksanakan tidak sekedar berorientasi High Order Thinking Skill, tetapi juga mengintegrasikan PPK, literasi dan kecakapan abad 21.

Berdasarkan hasil Best Pactice Peningkatan Apresiasi Konsep Karya Tari Berbantuan Media Rekaman Audio Visual Pada Siswa Kelas IX Semester 2 SMPN 1 Pecalungan Tahun Pelajaran 2019/2020, berikut disampaikan saran dan rekomendasi yang relevan antara lain : Guru seharusnya lebih bereksplorasi dan menambah variasi pembelajaran serta melakukan inovasi pembelajaran sehingga pembelajaran semakin bermakna. Siswa harus siap menerapkan kemampuan berpikir tingkat tinggi dalam belajar, tidak terbatas pada hafalan teori. Kemampuan belajar yang berorientasi High Order Thinking Skill akan membantu siswa menguasai materi lebih mendalam dan menguasai materi lebih banyak. Sekolah, terutama kepala sekolah dapat mendorong guru lain untuk melaksanakan pembelajaran berorientasi High Order Thinking Skill. Dengan dukungan positif dari sekolah, seperti penyedian sarana prasarana yang memadai dan kesempatan bagi penulis untuk mendesiminasikan Best Pactice ini, akan menambah wawasan guru lain tentang pembelajaran berorientasi High Order Thinking Skill. 
DAFTAR PUSTAKA

Beetlestone, Florence. 2012. “Creative Learning: Strategi Pembelajaran Untuk Melesatkan Kreativitas Siswa”. Bandung. Nusa Media.

Djamarah, Syaiful Bahri dan Aswan Zain. 2010. Strategi Belajar Mengajar. Jakarta: Rineka Cipta.

Ibrahim, M., \& Nur, M., (2000). Pengajaran berdasarkan Masalah. Surabaya : University Press.

Kapti, Suratmi Eka.2019. Program Pengembangan KeprofesianBerkelanjutan melalui Pengembangan Kompetensi Pembelajaran berbasis Zonasi SMP mapel seni Budaya.Jakarta.Dirjen Guru dan tenaga Kependidikan kementrian Pendidikan dan Kebudayaan.Halaman 20-22.

Kementrian Pendidikan dan Kebudayaan Republik Indonesia.2018. Seni Budaya kelas IX. Buku peserta didik. Jakarta. Pusat Kurikulum dan Perbukuan, Kemdikbud. halaman 75-87.

Kisbiyah, Yayah dan Atiqa Sabardila. 2004. Pendidikan Apresiasi Seni: Wacana dan Praktik untuk Toleransi Budaya. Surakarta: PSBPS UMS.

Masunah, Juju dan Tati Narawati. 2003. Seni dan Seni Pendidikan: Sebuah Bunga Rampai. Pusat Penelitian dan Pengembangan Pendidikan Seni Tari (P4ST) UPI. Bandung.

Republik Indonesia, BNSP/Permendiknas Nomor 22 Tahun 2006 tentang Standart Isi Untuk Satuan Pendidikan Dasar dan Menengah. Depdikbud :2006

Republik Indonesia, Peraturan Menteri Pendidikan dan Kebudayaan Nomor 81A Tahun 2013 tentang Implementasi Kurikulum. Depdikbud :2013

Republik Indonesia, Peraturan Pemerintah Nomor 19 Tahun 2005 tentang Standart Nasional Pendidikan.

Republik Indonesia, Undang - undang No 20 Tahun 2003 Tentang Sistem Pendidikan Nasional. 